\title{
Review \\ Volatile Solvents as Drugs of Abuse: Focus on the Cortico-Mesolimbic Circuitry
}

\author{
Jacob T Beckley ${ }^{1,2}$ and John J Woodward*,1,2 \\ 'Department of Neurosciences, Medical University of South Carolina, Charleston, SC, USA; ${ }^{2}$ Center for Drug and Alcohol Programs, Department \\ of Psychiatry/Neurosciences, Medical University of South Carolina, Charleston, SC, USA
}

\begin{abstract}
Volatile solvents such as those found in fuels, paints, and thinners are found throughout the world and are used in a variety of industrial applications. However, these compounds are also often intentionally inhaled at high concentrations to produce intoxication. While solvent use has been recognized as a potential drug problem for many years, research on the sites and mechanisms of action of these compounds lags behind that of other drugs of abuse. In this review, we first discuss the epidemiology of voluntary solvent use throughout the world and then consider what is known about their basic pharmacology and how this may explain their use as drugs of abuse. We next present data from preclinical and clinical studies indicating that these substances induce common addiction sequelae such as dependence, withdrawal, and cognitive impairments. We describe how toluene, the most commonly studied psychoactive volatile solvent, alters synaptic transmission in key brain circuits such as the mesolimbic dopamine system and medial prefrontal cortex (mPFC) that are thought to underlie addiction pathology. Finally, we make the case that activity in mPFC circuits is a critical regulator of the mesolimbic dopamine system's ability to respond to volatile solvents like toluene. Overall, this review provides evidence that volatile solvents have high abuse liability because of their selective effects on critical nodes of the addiction neurocircuitry, and underscores the need for more research into how these compounds induce adaptations in neural circuits that underlie addiction pathology.

Neuropsychopharmacology (2013) 38, 2555-2567; doi:I0.I038/npp.20I3.206; published online II September 20I3
\end{abstract}

Keywords: abused inhalants; toluene; prefrontal cortex; glutamate; dopamine

Volatile organic solvents are ubiquitous commodities in the modern world and used primarily for industrial purposes. Many of these chemicals are naturally abundant, found in geological formations and plants where they are extracted for commercial use. Volatile solvents are widely encountered by the general population because of their use in adhesives, cleaning agents, lacquers, and paints. They are also commonly used as fuels and in industrial extraction processes. The occupational exposure to volatile solvents is regulated in most countries, and there are numerous reports on the health effects of low-level exposures to solvents. The focus of this review, however, is on the voluntary use of inhalants for their psychoactive and rewarding properties. This is prompted by a growing appreciation that solvents have significant and selective effects on ion channels (Bowen et al, 2006), and neural circuits that subserve complex behaviors including those involved in reward and cognition. Thus, despite the previous conventional wisdom

\footnotetext{
*Correspondence: Dr JJ Woodward, Department of Neurosciences, Medical University of South Carolina, IOP 4 North, 67 President Street, MSC 86I, Charleston, SC 29425, USA, Tel: +(843) 792 5225, Fax: +(843) 792 7353, E-mail: woodward@musc.edu

Received 12 June 2013; revised 12 August 2013; accepted 13 August 2013; accepted article preview online 19 August 2013
}

that solvents affect the nervous system via non-selective breach of lipid membrane integrity, recent findings show that these agents have features in common with other major classes of addictive drugs.

Volatile solvents are a subgroup of compounds organized under the umbrella drug class of abused inhalants. Table 1 lists the different subtypes of abused inhalants with specific examples of each category. The common link between these chemicals is their low vapor pressure and high volatility at room temperature that supports their use as euphorigenic inhaled agents. There are some broad differences between each subcategory. Volatile anesthetics like isoflurane are used primarily in surgical settings and their predominant mechanism of action is probably because of an enhancement of GABAergic neurotransmission (Mihic and Harris, 1996; Mihic et al, 1997) and inhibition of glutamatergic ion channels (Ogata et al, 2006). Nitrous oxide is in a category of its own; it is currently used as an adjunct anesthetic to promote relaxation, and is commonly found in aerosol propellants, which give it the street names of 'laughing gas' and 'whippets,' respectively. Nitrous oxide has broad actions, including inhibition of NMDA glutamate receptors, stimulation of opioidergic and GABAergic transmission and possibly via imitation of nitric oxide (Emmanouil and Quock, 2007). Alkyl nitrites, sometimes known by their 
Table I Abused Inhalants Classification

\begin{tabular}{|c|c|c|}
\hline Category & Chemicals & Most common sources \\
\hline \multicolumn{3}{|l|}{ Volatile solvents } \\
\hline $\begin{array}{l}\text { Aromatic } \\
\text { hydrocarbons }\end{array}$ & $\begin{array}{l}\text { Toluene } \\
\text { Ethylbenzene } \\
\text { Xylene }\end{array}$ & $\begin{array}{l}\text { Adhesive, spray paint, thinner, } \\
\text { lacquer, leather tanner, } \\
\text { disinfectant, cleaner, petroleum, } \\
\text { octane booster }\end{array}$ \\
\hline Halocarbons & $\begin{array}{l}\text { Trichloroethylene (TCY) } \\
\text { I, I, I-trichloroethane (TCE) } \\
\text { Tetrachloroethylene (PERC) } \\
\text { n-Propyl Bromide (nPB) }\end{array}$ & $\begin{array}{l}\text { Degreasing agent, coffee } \\
\text { decaffeination } \\
\text { Film cleaner, correction fluid } \\
\text { Dry cleaning agent, degreasing } \\
\text { agent } \\
\text { Metal cleaner, adhesive }\end{array}$ \\
\hline $\begin{array}{l}\text { Aliphatic } \\
\text { hydrocarbons }\end{array}$ & $\begin{array}{l}\text { Propane } \\
\text { Butane } \\
\text { n-Hexane } \\
\text { Iso-octane }\end{array}$ & $\begin{array}{l}\text { Domestic and industrial fuel } \\
\text { Lighter fluid } \\
\text { Adhesive } \\
\text { Automotive fuel }\end{array}$ \\
\hline $\begin{array}{l}\text { Inhaled anesthetics } \\
\text { Halogenated } \\
\text { ethers }\end{array}$ & $\begin{array}{l}\text { Isoflurane } \\
\text { Desflurane } \\
\text { Sevoflurane }\end{array}$ & General anesthetic \\
\hline Nitrous oxide & Nitrous oxide & $\begin{array}{l}\text { Adjunct anesthetic, } \\
\text { aerosol propellant }\end{array}$ \\
\hline Alkyl nitrites & $\begin{array}{l}\text { Amyl nitrite } \\
\text { Isobutyl nitrite } \\
\text { Isopropyl nitrite }\end{array}$ & $\begin{array}{l}\text { Vasodilator, heart disease } \\
\text { treatment, air freshener, } \\
\text { electronics cleaner, cyanide } \\
\text { poisoning antidote }\end{array}$ \\
\hline
\end{tabular}

street name 'poppers,' are strong vasodilators, an effect that explains their medical use in the treatment of heart disease. Nitrites possibly work by stimulating the release of nitric oxide and the concomitant activation of cyclic GMP, although it is unclear whether this mechanism is responsible for their intoxicating properties (Balster, 1998). While agents in all of these categories are intentionally used for intoxication, volatile solvents are cheap and easy to obtain and are the most commonly used class of abused inhalants. The vast majority of solvent products used for inhalation contain a mixture of volatile compounds. This is illustrated in the analysis of the U.S. Poison Control data from 1993 to 2008 that reported over 35000 cases of excessive solvent inhalation. These cases involved over 3000 different products that contained a putative abused inhalant (Marsolek et al, 2010). However, some volatile solvents, like toluene, are the dominant chemical in products such as glues or thinners that are widely used for intoxication. Toluene is also strongly psychoactive and has a well-researched pharmacological profile. Most basic research studies on inhalants have investigated the actions of a single volatile solvent at a time and in a majority of cases, toluene is the solvent of choice.

Research on the abuse potential and addictive properties of volatile solvents has lagged behind that of other illicit drugs of abuse. In this review, we make the case that due to their epidemiology, pharmacology, and effects on mesocortical and mesolimbic circuitry, volatile solvents are harmful products that have a high abuse liability and should receive additional research attention.

\section{CLINICAL PERSPECTIVES}

The intoxicating effects of abused inhalants have been recognized for two centuries. In the mid-19th century, 'gas frolics' were popular recreational events where paying a fee enabled one to inhale nitrous oxide, ether, or chloroform, or watch those who were similarly intoxicated (Garland et al, 2011). However, the intentional misuse of volatile solvents was not reported in clinical case reports or popular press until the mid-twentieth century. The first documented case was in 1946, when a boy, who was being treated for psychotic symptoms at a hospital, admitted to the attending physician that he chronically and uncontrollably inhaled gasoline for its intoxicating effects (Clinger and Johnson, 1951). A decade later, the press from major American cities started reporting on the increasingly popular phenomenon of intentional glue sniffing among youth, and medical professionals started to become aware that solvents were euphorigenic and could possibly produce psychological dependency (Glaser and Massengale, 1962). It is now widely accepted that volatile solvents are a distinct class of abused drugs, and chronic solvent use can lead to a substance use disorder (abuse or dependence), as defined by DSM-IV. In one study of frequent solvent users, $35 \%$ of subjects met the criteria for substance abuse while $28 \%$ met the criteria for dependence. Furthermore, $10.5 \%$ of users displayed tolerance to solvents, and $11 \%$ showed signs of withdrawal upon cessation of solvent use (Ridenour et al, 2007). In another study, a cohort of patients who met the criteria for inhalant dependence used a questionnaire to report on the interoceptive effects of inhalants. Users commonly stated that solvents induced pleasant feelings, or 'drunkenness;' that they evoked drug seeking and moderate psychological withdrawal, with symptoms like craving and restlessness; and that solvents could induce psychotic symptoms such as emotional volatility, hallucinations, and delusions (Miyata et al, 2004). While there have not been many clinical observations of solvent abusers, the available information strongly suggests that volatile solvents can be profoundly intoxicating and that chronic use produces addiction pathology similar to other abused drug classes, like cocaine or opiates.

Volatile solvent abuse can also lead to major cognitive impairment (Dingwall and Cairney, 2011). Chronic abusers of solvents show impairments in short-term memory, attention, response inhibition, and problem solving, and these impairments often persist even after long periods of abstinence (Dingwall et al, 2011; Fornazzari et al, 1983; Hormes et al, 1986; Kamran and Bakshi, 1998; Ryu et al, 1998; Takagi et al, 2011; Yücel et al, 2008). This may be due to solvent-induced loss of white matter volume throughout the brain (Rosenberg et al, 1988) with a particularly high level of white matter abnormalities found in the frontal and temporal lobes (Yücel et al, 2010), regions that are critical mediators of higher-order cognitive tasks (Curtis and D'Esposito, 2003; Curtis and Lee, 2010; Dalley et al, 2004). Chronic solvent users also show comorbidity with other mental impairments such as mood disorders like major depression and antisocial personality disorder (Sakai et al, 2004; Zubaran et al, 2010). The likelihood of comorbidity with mood or personality disorders was significantly higher in individuals who tried inhalants before the age of 13 (Wu and Howard, 2007). The overall consensus of these data is that intentional solvent misuse causes serious CNS 
disturbances including addiction pathology and cognitive impairments, with these effects persisting even after long periods of abstinence.

\section{EPIDEMIOLOGY}

\section{Volatile Solvents in America}

Abused inhalants are voluntarily inhaled for their euphorigenic effects by a surprisingly high proportion of American adolescents. According to the 2013 Monitoring the Future study, the 30-day prevalence rate for intentional volatile solvent use among American 8th graders, or mostly 12- to 14 -year-olds, was $2.7 \%$. This prevalence is higher than all usage rates for all other illicit drugs except marijuana, and this trend has held steady for the past two decades (Johnston et al, 2013; Figure 1). Moreover, the true prevalence of solvent use may be higher due to incorrect self-reporting of inhalant use. To wit, in a longitudinal study, $49 \%$ of 7 th graders who admitted to volatile solvent misuse recanted the following year, and the researchers predicted that the vast majority of recanters were actual solvent users (Martino et al, 2009). Volatile solvents are most commonly misused by young adolescents, with an age at peak use of 14 years (Marsolek et al, 2010; Nonnemaker et al, 2011). Caucasian and Native American populations have the highest voluntary exposure frequency among American adolescents, with African-Americans well below average prevalence (Beauvais et al, 2002; Wu et al, 2011). There is some evidence that volatile solvent misuse is highest among those living in isolated communities (Lubman et al, 2008). For example, the incidence of intentional volatile solvent use among adolescents in rural Alaska is higher than all other drugs except alcohol (Driscoll et $a l, 2012)$. Intentional solvent inhalation is also likely more common among those living in poverty, as the odds of an adolescent initiating solvent use has been shown to be inversely proportional to total family income (Nonnemaker et al, 2011). Delinquency, antisocial behavior, and selfinflicted harm are also likely good predictors of volatile solvent misuse. For example, in a survey among incarcerated youth, users, and those who met the DSM- IV criteria for inhalant abuse or dependence had much higher rates of attempted suicide (30.2 and 63.3\%, respectively) than those who had not misused solvents (17\%, (Freedenthal et al, 2007). Notably, among members of the American military, volatile solvent prevalence mirrors the general population, whereas the use of other drugs such as marijuana, cocaine, and amphetamine is much lower (Lacy and Ditzler, 2007). This is likely a result of the use of random drug screens by the military that includes most illicit drugs, but not volatile solvents.

\section{Volatile Solvents Worldwide}

Volatile solvents are ubiquitous worldwide especially in industrialized nations, and the demand is increasing due to the growth of rapidly emerging markets in developing countries. As such, the intentional inhalation of volatile solvents is a global phenomenon. In some countries, the prevalence is lower in the United States. For example, while American 8th to 12 th graders have a lifetime prevalence of

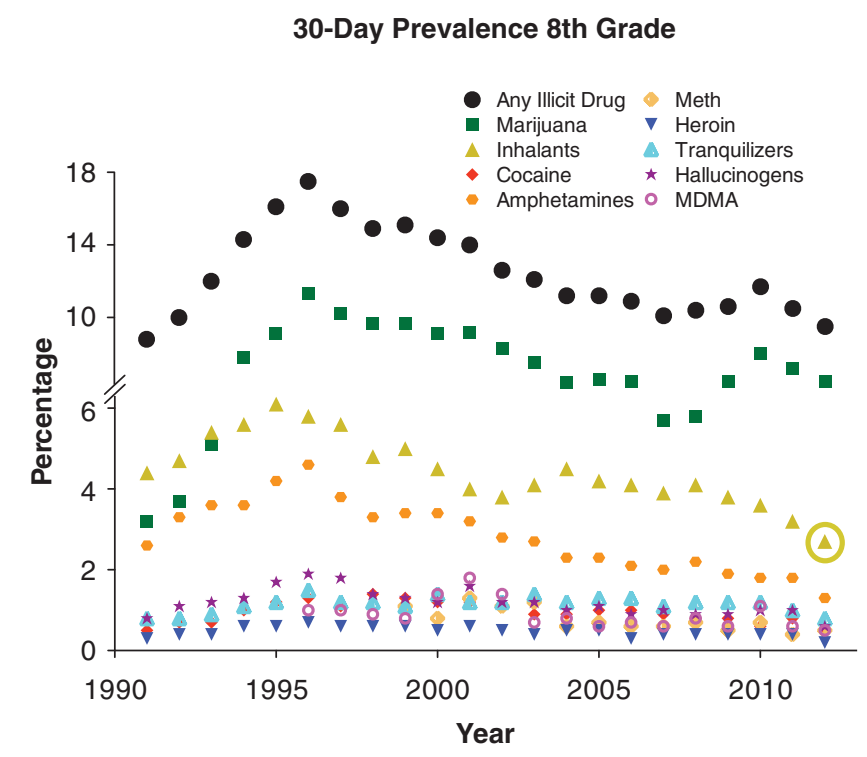

Figure I Trends in 30-day prevalence for voluntary use of various drugs among American 8th grade students. Solvents are indicated by triangles with the final point being encircled. Data from Johnston et al (20/3).

$10 \%$ (Johnston et al, 2013), the rate among Canadian 12- to 17 -year-olds is around 3 to 5\% (Weir, 2001), and among Japanese equivalent 1 st to 12 th grader, the rate is $1.2 \%$ (Kikuchi and Wada, 2003). Annual prevalence for volatile solvent misuse among high school students in Mexico City, Mexico is $4.1 \%$ (Villatoro et al, 2011) and among Bogota, Colombia students, the rate is $3.4 \%$ (Lopez-Quintero and Neumark, 2011), both cases being slightly lower than annual incidence among high school students in the United States (4.6\%, (Johnston et al, 2013). However, prevalence of volatile solvent misuse is likely much higher among street children in Mexico City, and probably throughout Latin America. (Villatoro et al, 2011). Brazil has perhaps the highest prevalence of intentional solvent use among the general population, as the past month prevalence rate among high school students is $10.3 \%$ (Hynes-Dowell et al, 2011). Overall, volatile solvent incidence in South American countries is higher than much of the world, and the peak use occurs among 18-year-olds in Bolivia, Brazil, Colombia, and Peru (Hynes-Dowell et al, 2011), a pattern of use that is in striking contrast to American epidemiological patterns.

Marginalized populations worldwide, whether impoverished or living in isolated communities, likely have the highest rates of volatile solvent misuse. For example, among the Roma people of Eastern Slovakia, the incidence of chronic inhalant abuse is around $2 \%$ for all people over 10 years of age (Važan et al, 2011), and in some Australian indigenous communities, over $10 \%$ of people over the age of 12 are chronic inhalant abusers (Cairney et al, 2002). Overall, findings from epidemiological studies are clear and consistent and show that the intentional misuse of volatile solvents is a global phenomenon, and is concentrated among adolescents. This is particularly concerning as inhalation of solvents at extremely high vapor concentrations negatively impacts the nervous system and behavior, and these effects may be magnified when misuse occurs 
during adolescence due to the profound behavioral, cognitive, and neural development that occurs during this stage in life.

\section{PHARMACOLOGY}

The predominant route of administration of volatile solvents is through inhalation of fumes, known in street terms as 'huffing,' or 'chroming' (Lubman et al, 2008). Toluene is detectable by humans at concentrations as low as 11 p.p.m. (World Health Organization, 2000), and a lowdetectable concentration is probably common among other volatile solvents. In contrast, those who intentionally inhale volatile solvents for intoxication usually expose themselves for a short duration (around $15 \mathrm{~min}$ ) to extremely high vapor concentrations, up to 15000 p.p.m. (Hathaway and Proctor, 2004).

Toluene likely has the most well-documented pharmacological profile of all the volatile solvents studied. While the majority of the toluene vapor exhaled is unchanged, the rest enters the bloodstream through the alveoli and distributes throughout the body (Garcia, 1996). Ten minutes following initiation of vapor inhalation, the blood concentration of toluene in rats reaches about $60 \%$ of maximum, and then drops to around $30 \%$ of maximum $40 \mathrm{~min}$ following cessation of inhalation (Benignus, 1981). Due to excretion from lungs and metabolism, it is estimated that about $3 \%$ of the original vapor concentration of toluene reaches the brain (Benignus et al, 1981).

Toluene acts as a central nervous system depressant, and it is likely that all volatile solvents act similarly, although potency and sites of action may differ between solvent type. Like ethanol, the most commonly used CNS depressant, toluene, benzene, $m$-xylene, ethylbenzene and 1,1,1-trichloroethane (TCE) dose-dependently and reversibly inhibit NMDA receptors, with a higher potency on GluN1/2B than GluN1/2A receptors (Cruz et al, 1998, 2000). Toluene, TCE, and trichloroethylene (TCY) also enhance $\mathrm{GABA}_{\mathrm{A}}$ and glycine receptor function (Beckstead et al, 2000, 2001). In the hippocampal CA1 synapses, toluene enhances GABAergic neurotransmission by increasing the intracellular calcium concentration in the presynaptic terminal, leading to an increased release of GABA (MacIver, 2009). While volatile solvents pharmacologically inhibit NMDARs and enhance $\mathrm{GABA}_{\mathrm{A}}$ activity, prolonged exposure to inhalants leads to a homeostatic process whereby NMDA-mediated currents are enhanced and $\mathrm{GABA}_{\mathrm{A}}$ currents are diminished (Bale et al, 2005). NMDA and $G_{A B A}$ receptor subunit expression follows this homeostatic response as well, with an increase in GluN1 expression in the medial prefrontal cortex (mPFC), GluN2B in the NAc and VTA, and a decrease in $\mathrm{GABA}_{\mathrm{A}} \alpha 1$ subunit expression in the VTA and substantia nigra (Williams et al, 2005). Therefore, toluene and likely other volatile solvents bi-directionally affect inhibitory and excitatory synaptic transmission depending on whether exposure is acute or chronic.

While toluene's action on the GABA and glutamate neurotransmitter systems likely underlies much of its CNS depressant effects, toluene has also been shown to act on a number of other ion channels and modulatory processes.
Thus, toluene affects synaptic signaling by increasing intracellular levels of calcium in both glutamatergic and GABAergic neurons, and this action is blocked by dantrolene, a ryanodine receptor antagonist, or thapsigargin, a SERCA inhibitor (Beckley and Woodward, 2011; MacIver, 2009), suggesting an interaction with intracellular receptors that gate calcium stores. Toluene also dosedependently inhibits nicotinic acetylcholine receptors, with $\alpha 4 \beta 2$ and $\alpha 3 \beta 2$ subtypes being particularly sensitive (Bale et al, 2002). Toluene, along with TCE and TCY and ethanol, also enhances serotonin 5HT3 function (Sung et al, 2000; Lopreato et al, 2003). Toluene's effect on 5HT3 receptors may be important in mediating its rewarding properties, as 5HT3 activation synergizes with systemic administration of ethanol in enhancing extracellular DA in the NAc (Campbell and McBride, 1995), and in alcohol-dependent individuals, ondansetron, a 5HT3 antagonist, reduces BOLD changes due to alcohol cues in the ventral striatum (Myrick et al, 2008). In contrast to ethanol, toluene inhibits the calciumactivated potassium BK channel and also the G-protein coupled inwardly rectifying potassium channel GIRK2 (Del Re et al, 2006). On the other hand, ethanol, anesthetics, toluene, TCE, and tetrachloroethylene, also known as perchloroethylene (PERC), all inhibit voltage-sensitive calcium current-mediated voltage-gated calcium channels (Shafer et al, 2005; Tillar et al, 2002). Toluene also inhibits voltage-gated sodium channels, with cardiac subtypes being more sensitive than those expressed in neurons (Cruz et al, 2003; Gauthereau et al, 2005). This mechanism may relate to an abuser's development of 'Sudden Sniffing Death Syndrome,' which is a form of cardiac failure resulting from acute, high concentration exposure to volatile solvents (Kurtzman et al, 2001). Toluene has a complex interaction with ATP-sensitive P2X receptors, producing inhibition of $\mathrm{P} 2 \mathrm{X} 2$ and P2X4 receptors activated by low, but not maximal, ATP concentrations, and potentiating currents in P2X3 receptors at all tested ATP concentrations (Woodward et al, 2004). Other effects of toluene include inhibition of gap junction connexin channels involved in intercellular communication (Del Re and Woodward, 2005). These diverse actions are summarized in Figure 2 and illustrate the wide range of potential targets for toluene in the CNS. Based on these findings, it can be hypothesized that toluene and other volatile solvents would have profound effects on fast synaptic transmission mediated by calcium-dependent release of neurotransmitters and activation of ligand-gated ion channels with less effect on axonal conduction. Differences in the expression of toluenesensitive and insensitive targets between brain regions and during development would also be expected to determine the sensitivity of various behaviors or brain processes to volatile solvents. As discussed below, some of these actions have been examined using animal models of drug discrimination/reinforcement and single neuron electrophysiological approaches.

\section{PRECLINICAL PERSPECTIVES}

\section{Drug Discrimination}

The broad range of pharmacological targets of abused inhalants has made determining which receptor-mediated 


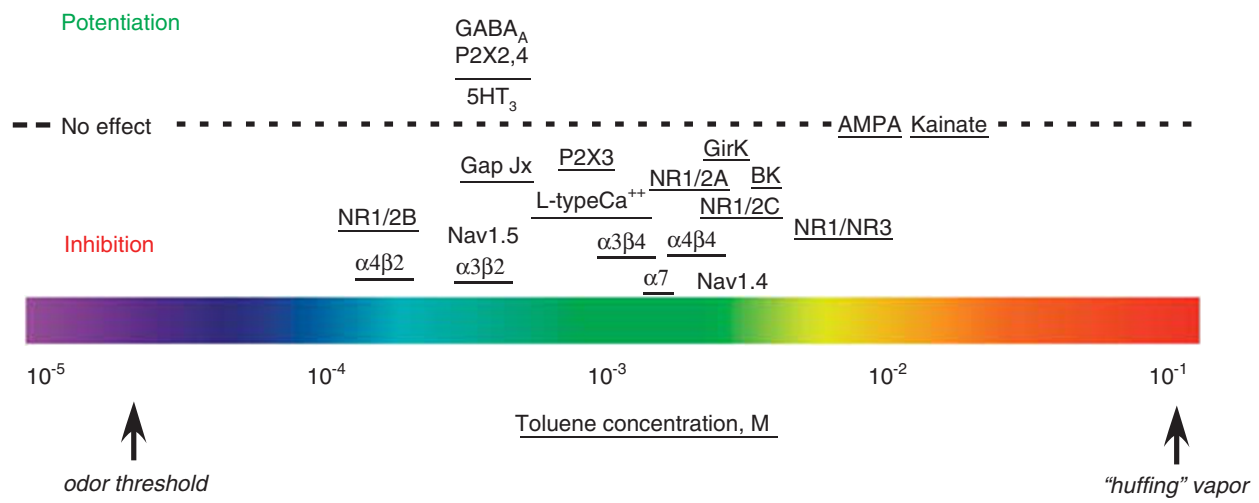

Figure 2 Toluene dose-dependently alters the activity of a wide range of ion channels. Color bar indicates relative range of concentrations of toluene with odor threshold and huffing concentration indicated. Position of ion channel along the $x$-direction indicates relative sensitivity of individual ion channels to toluene while position along the $y$-direction indicates inhibition (below dotted line) or potentiation (above dotted line). Toluene has no appreciable effect on ion channels that overlay the dotted line. Underline indicates data collected in the author's laboratory.

effects underlie their specific behavioral responses complex. Fortunately, the drug discrimination paradigm is an effective way to interrogate the involvement of specific receptors in drugs' interoceptive properties. In the earliest drug discrimination studies, rodents were trained to discriminate between saline and a drug of abuse, such as ethanol, on a two-lever operant task. Following training, subjects were then exposed to a volatile solvent and responses on the saline and ethanol levers were measured as an indication of whether the solvent was ethanol-like. Results from these studies confirmed that volatile solvents such as toluene and TCE have interoceptive CNS depressant effects and show full substitution for ethanol (Rees et al, 1987b) and pentobarbital (Rees et al, 1985, 1987a). Toluene's ability to substitute for $1 \mathrm{~g} / \mathrm{kg}$ ethanol is nearly abolished when vapor concentrations reach 5400 p.p.m., but this may reflect overall motor impairment as animals that could respond still chose the lever associated with ethanol. The time course for the ethanol discriminative stimulus effect of toluene and TCE parallels the rapid pharmacokinetic profile of these solvents as responding on the appropriate lever is nearly abolished $20 \mathrm{~min}$ post-inhalation, confirming that volatile solvents have a much shorter halflife than ethanol. Toluene also partially substitutes for amphetamine (Bowen, 2006), suggesting that toluene produces alterations in DA activity.

To attempt to hone in on the channels and specific binding sites that are necessary for the intoxicating properties of volatile solvents, researchers have shifted from using other drugs of abuse as training compounds for the use of the abused inhalant as the discriminative stimulus and then testing these animals with selective receptor agonists. Mice will fully discriminate vaporized toluene from air at concentrations between 4000 and 12000 p.p.m., and the discriminative time course mirrors the falling blood concentration after vapor concentration (Shelton and Slavova-Hernandez, 2009). Similarly, TCE can act as a discriminative stimulus, and other volatile solvents like toluene, ethylbenzene, o-xylene, TCY, and PERC all substitute for TCE (Shelton, 2009). In terms of selective channel agonists or antagonists, the benzodiazepine (BZ) midazolam partially substitutes for TCE, an effect that is blocked by the BZ-site antagonist flumazenil. Interestingly, flumazenil does not block the discriminative stimulus effects of TCE (Shelton, 2010). Zaleplon, a BZ-site positive modulator with strong selectivity for $\mathrm{GABA}_{\mathrm{A}}$ channels containing the $\alpha 1$ subunit, has a lower substitution level (39\%) than midazolam, indicating that TCE may preferentially act on $\alpha 1$-lacking $\mathrm{GABA}_{\mathrm{A}}$ receptors (Shelton and Nicholson, 2012). Interestingly, neither the competitive NMDA antagonist CGS-19755 nor the non-competitive NMDA antagonists phencyclidine or MK-801 substitute for TCE, implying that, despite the fact that TCE is a NMDA antagonist, this site of action may not be necessary for its interoceptive properties.

\section{Reward Related Animal Models}

The reinforcing effects of toluene have been probed by using various animal models associated with different aspects of drug addiction. Locomotor effects of drugs have been commonly studied due to the fact that increased mesolimbic dopamine activity, historically thought of as the 'reward pathway,' induces hyperlocomotion. As for other CNS depressants, the locomotor effects of toluene follow a inverted U-shaped dose-response curve, with concentrations around $700-1000$ p.p.m. inducing hyperlocomotion, an effect attributable to increased dopamine release in the nucleus accumbens (Lo et al, 2009; Riegel and French, 1999; Riegel et al, 2003). Relatedly, repeated toluene exposure produces locomotor sensitization, an effect that crosssensitizes with the hyperlocomotive effects of cocaine (Beyer et al, 2001). Intriguingly, both the acute hyperlocomotion and locomotor sensitization effects of toluene are more pronounced in adolescent rats (Batis et al, 2010), suggesting that, compared with adults, toluene exposure during adolescence may induce a larger DA surge in the striatum. Beyond locomotion, both rats and mice show conditioned place preference to toluene, providing evidence that even passive exposure to toluene vapor is rewarding (Funada et al, 2002; Gerasimov et al, 2003; Lee et al, 2006). Furthermore both mice and non-human primates will self-administer intravenous or vaporized toluene, respectively (Blokhina et al, 2004; Weiss et al, 1979), indicating that toluene has reinforcing properties that subjects 
will work to obtain, a signature characteristic of addictive drugs.

\section{TOLUENE AND THE MESOCORTICOLIMBIC SYSTEM}

\section{Toluene and Mesolimbic DA}

The preclinical findings corroborate the clinical evidence and firmly establish toluene as a positive reinforcer, but the mechanism as to how toluene induces prolonged synaptic adaptations that could potentially trigger addictive pathology have not been completely elucidated. Nevertheless, similar to other drugs of abuse (Di Chiara and Imperato, 1988), toluene dose-dependently increases extracellular dopamine levels in the nucleus accumbens and the PFC (Gerasimov et al, 2002; Riegel et al, 2007). These effects are dose-dependent, as concentrations below 3000 p.p.m. do not alter dopamine release, but 7000 p.p.m. toluene produces robust DA and norepinephrine release in the PFC and NAc. The enhancement of DA in the NAc lasts for over $1 \mathrm{~h}$ following a $30 \mathrm{~min}$ vapor exposure, while the increase in PFC DA levels returns to basal levels within $45 \mathrm{~min}$ (Gerasimov et al, 2002; Koga et al, 2007). These increases may reflect enhanced firing of VTA DA neurons during toluene exposure. In rat slices, Riegel et al (2007) showed that toluene, at a concentration as low as $370 \mu \mathrm{M}$, increased tonic firing of putative DA neurons located within, but not outside of the VTA. This concentration is far lower than the concentration required to increase extracellular DA levels in the NAc. This is likely because much higher toluene concentrations are needed to switch DA neurons from tonic to burst firing mode, the firing pattern required to increase DA in the NAc and to produce conditioned place preference (Tsai et al, 2009). It is still not understood how toluene or other solvents actually increase VTA DA neuron activity, and this has been difficult to pinpoint due to the wide variety of sites of action. It is likely that these effects result both from direct actions of toluene on processes that regulate the intrinsic activity of VTA DA neurons and indirectly via modulation of inhibitory and excitatory inputs that impinge upon these neurons.

\section{Toluene and Mesolimbic Plasticity}

Along with increasing extracellular dopamine levels in the nucleus accumbens, abused drugs of all classes also induce a prolonged enhancement of glutamatergic synaptic strength on VTA DA neurons (Heikkinen et al, 2009; Mansvelder and McGehee, 2000; Saal et al, 2003; Ungless et al, 2001). For cocaine, this is likely due to a postsynaptic insertion of GluA2-lacking, calcium-permeable AMPA receptors (Argilli et al, 2008). Drug-induced adaptations in glutamatergic synaptic transmission is thought to be critically important in the progression from recreational to compulsive drugtaking, as VTA DA plasticity is necessary for synaptic alterations in the downstream NAc medium spiny neurons (Mameli et al, 2009). For most drugs, it is not clear how long this alteration persists, as previous experiments have generally recorded from putative DA neurons randomly selected in the VTA. However, there is a building appreciation that VTA DA neurons are heterogeneous and exhibit biochemical and physiological diversity that reflects their specific anatomical connections (Bjorklund and Dunnett, 2007; Ford et al, 2006; Lammel et al, 2008). For example, using a targeted recording approach, it was shown that the altered glutamatergic plasticity of mesoaccumbens medial shell projecting DA neurons persists for at least 21 days following a single cocaine injection (Lammel et al, 2011).

Research from the author's lab has shown that rats exposed in vivo to 5700 p.p.m., but not 2850 p.p.m. toluene, increased the AMPA/NMDA ratio in mesoaccumbens core projecting DA neurons for at most 6 days. This effect, like that observed for cocaine, appears to be due to insertion of calcium-permeable GluA2-lacking AMPA receptors. Intriguingly, 5700 p.p.m. toluene enhanced the AMPA/NMDA ratio in mesoaccumbens medial shell projecting DA neurons for at least 21 days (Beckley et al, 2013, Figure 3). Differential effects of drugs on NAc medial shell and core projecting neurons have been demonstrated previously, as cocaine more robustly enhances extracellular DA concentration in the medial shell compared with the core (Aragona et al, 2008). Differences in sensitivity of NAc projecting DA neurons to abused drugs may reflect the underlying circuitry that link reward and motor output pathways. The basal ganglia brain regions are interconnected in partially rectified, yet reciprocating hierarchical loops, with the mesostriatal component following the same pattern (Everitt and Robbins, 2005; Haber et al, 2000). The NAc medial shell is on the ventromedial axis of the basal ganglia, receives stronger input from and has more output to limbic regions than the core (Groenewegen et al, 1993; Humphries and Prescott, 2010; Ikemoto, 2007; Maurice et al, 1999; Usuda et al, 1998). Because of this anatomy, the druginduced alteration of excitatory transmission onto mesoaccumbens medial shell neurons may be more pronounced after a single use. Then, following continued drug use, neurons located closer to the dorsolateral axis, such as nigrostriatal DA neurons, may be more robustly affected, leaving the machinery that encodes goal-directed behavior biased towards the drug of abuse. This hypothesis is strengthened by research showing that while a single cocaine injection has no effect on synaptic transmission onto nigrostriatal neurons (Lammel et al, 2011), repeated drug exposures strongly engage the dorsal striatum. The dorsolateral striatum is critical for habit formation (Balleine et al, 2007; O'Doherty et al, 2004) and is necessary for compulsive cocaine-taking rats to show resistance to devaluation of a reward; a sign of habitual behavior (Everitt and Robbins, 2005). While further research is needed to determine the impact of toluene and other volatile solvents on the dorsolateral components of the basal ganglia, it is clear that toluene engages the mesolimbic system like other drugs of abuse.

\section{Toluene and the mPFC}

In contrast to mesoaccumbens DA neurons, a single administration of cocaine or toluene does not alter excitatory synaptic strength onto mesocortical DA neurons (Beckley et al, 2013; Lammel et al, 2011). While this suggests that a mesocortical circuit is not actively involved in mediating the acute actions of drugs of abuse, recent findings from our laboratory suggest that MPFC neurons 
a

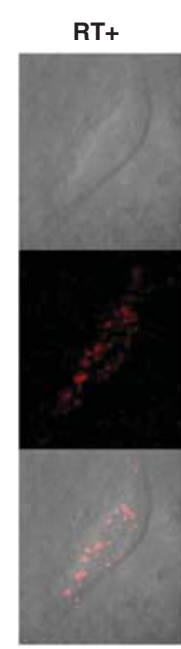

b

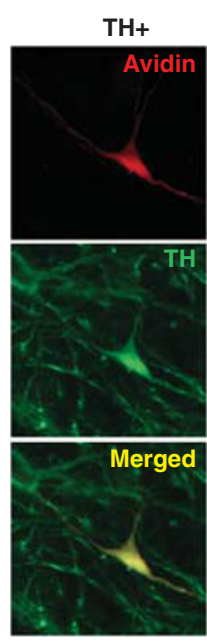

C

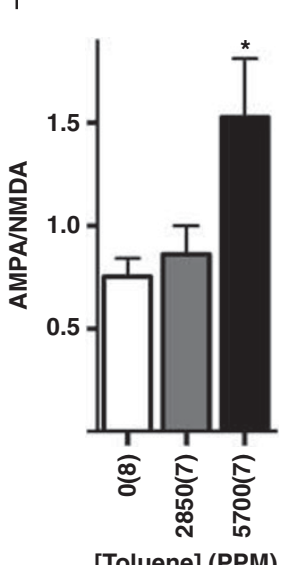

[Toluene] (PPM)
NAcc $>$ VTA

ii
*

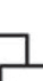

iii

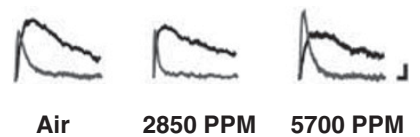

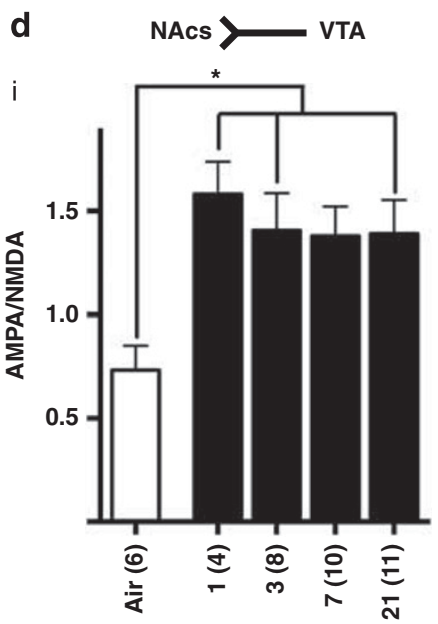

Days following 5700 PPM toluene exposure

ii

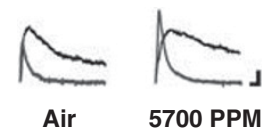

Figure 3 Toluene enhances excitatory transmission onto mesolimbic neurons. (a) Example of a VTA neuron that expresses red retrobeads. (b) Representative example of a recorded neuron in the VTA that is TH+. (c) Summary effects of in vivo toluene on AMPA/NMDA ratio from mesoaccumbens core neurons. (i) Dose-depedency of toluene's actions on the AMPA/NMDA ratio (*p<0.05). (ii) Toluene's effect persists for at most 6 days (*p $<0.05$ ). (iii) Representative AMPA and NMDA traces from mesoaccumbens core neurons. (d) Summary of effects on mesolimbic shell neurons. (i) Toluene's effect on AMPA/NMDA ratio persists at least 21 days (*p<0.05). (ii) Representative AMPA and NMDA traces from mesolimbic shell neurons. From Beckley et al, 2013; with permission from the Journal of Neuroscience.

are critical regulators of drug-induced changes in synaptic plasticity of mesoaccumbens DA neurons. These experiments showed that pharmacologically enhancing mPFC activity in rats just prior to vapor exposure completely blocked toluene's ability to enhance excitatory transmission onto mesoaccumbens core neurons. Furthermore, inactivating the $\mathrm{mPFC}$ in animals prior to toluene vapor exposure converted a previously ineffective concentration (2850 p.p.m.) of toluene vapor to one that robustly enhanced the synaptic strength of NAc projecting DA neurons (Beckley et al, 2013). These findings demonstrate that the mPFC gates toluene's actions on mesolimbic synaptic transmission, presumably through an inhibitory intermediary. The relationship between $\mathrm{mPFC}$ glutamatergic neuronal output and VTA DA neuron activity is likely complex and mPFC stimulation is reported to both excite or inhibit DA neuron activity (Aston-Jones et al, 2009; Gao et al, 2007; Lodge, 2011; Tong et al, 1996). This discrepancy could reflect differences between the studies in recording sites used as well as the state of DA neuron activity at the time of PFC stimulation. In a study by Gao et al (2007) that evaluated basal in vivo activity, a majority of VTA DA neurons displayed a slow oscillation in firing that was abolished when tetrodotoxin was applied to the mPFC. The decrease in firing of DA neurons during these oscillations was temporally correlated with the initiation of upstates in mPFC neurons; periods of sustained depolarization were accompanied by action potential firing. These results are consistent with an inverse relationship between $\mathrm{mPFC}$ activity and VTA DA neuron firing that implicates an intermediate inhibitory cell type in this circuit. In non-DA VTA neurons, PFC upstates and firing showed an in-phase relationship, consistent with the inverse relationship between PFC and VTA DA activity. This elegant study from Gao et al (2007) strongly suggests that, at least in terms of spontaneous activity in vivo under anesthesia, the mPFC exerts inhibitory control over VTA DA neurons.

Tract tracing also provides evidence that the mPFC provides inhibitory tone over the mesolimbic pathway. Thus, although mPFC sends robust efferents to the VTA (Gabbott et al, 2005), few of these synapse directly onto mesolimbic projecting DA neurons (Watabe-Uchida et al, 2012). Instead, mPFC projections terminate onto spines of mesocortical, but not mesolimbic DA neurons and onto local and NAc projecting GABA interneurons (Carr and Sesack, 2000). Within the VTA, GABAergic neurons inhibit VTA DA neurons (Omelchenko and Sesack, 2009) and selectively activating VTA GABA neurons using optogenetics interrupts reward consumption (Van Zessen et al, 2012) and produces conditioned place aversion (Tan et al, 2012).

The mPFC can also inhibit mesolimbic dopaminergic activity through a number of other pathways, with the corticohabenular tract being potentially critically important in regulating the mesolimbic DA system. The mPFC densely innervates the habenula $(\mathrm{Hb})$, with a similar topography as the basal ganglia (Haber et al, 2000); that is, ventromedial aspects of the mPFC project to the medial habenula (MHb) whereas more dorsal components, like the cingulate gyrus, project to the LHb (Kim and Lee, 2012). The MHb is unique in that it supplies a dense excitatory cholinergic projection to the interpeduncular nucleus (IPN (Girod et al, 2000)), a collection of GABAergic neurons that lie beneath the cerebral peduncles in the midbrain (Kawaja et al, 1989). 
IPN neurons receive direct input from the vmPFC (Takagishi and Chiba, 1991) and their output can provide powerful inhibitory tone in areas including the VTA. IPN neurons are inhibited by toluene (Riegel et al, 2007), possibly due to toluene-mediated inhibition of nicotinic cholinergic receptors (Bale et al, 2002) that are densely expressed on both presynaptic terminals from the medial habenula $(\mathrm{mHb})$ and postsynaptic spines on IPN neurons (Grady et al, 2009). There is strong evidence that the IPN is a critical limbic brain region with influence over VTA DA activity. For example, tetrodotoxin injected to the fasciculus retroflexus, the nerve bundle that carries the habenulointerpeduncular tract (HIT), leads to an increase in DA and homovanillic acid in the mPFC and NAc, suggesting that inhibiting the HIT disinhibits VTA DA neuron activity (Nishikawa et al, 1986). The LHb provides a different inhibitory route to the mesolimbic DA system, via a dense projection to the GABA-rich rostromedial tegmental nucleus (RMTg) (Jhou et al, 2009), also known as the tail of the VTA (Kaufling et al, 2009). Activation of the RMTg results in VTA DA neuronal inhibition (Christoph et al, 1986; Ji and Shepard, 2007) and disrupts reward-based responding (Lammel et al, 2012; Stamatakis and Stuber, 2012). Based on its connectivity with VTA GABA interneurons, the MHb, LHb, IPN, and RMTg, the MPFC provide strong inhibitory regulation of the mesolimbic DA system (Figure 4). Ultimately, the PFC's top-down inhibitory regulation confers its function in cognition and overall contribution to goal-directed behavior (O'Reilly, 2006).

Contributing to the notion that the $\mathrm{MPFC}$ is a critical target for drugs of abuse at both the recreational and compulsive drug-taking stages, these agents appear to alter mPFC activity directly. Cocaine has been shown to acutely depress the cortical activity (Trantham-Davidson and Lavin, 2004), and excessive DA tone on PFC neurons blocks the formation of LTP via the D2 receptor and protein phosphatase 1 (Xu et al, 2009). While all CNS depressants likely depress cortical output by pharmacologically inhibiting NMDAR and/or promoting $\mathrm{GABA}_{\mathrm{A}}$ activity, toluene produces long-term depression of AMPA signaling in deep-layer mPFC pyramidal neurons, an effect mediated by endocannabinoids (Beckley and Woodward, 2011). Corroborating with the electrophysiology, a single exposure to toluene also produces dysfunction in a behavioral flexibility task that outlasts its motor impairment effects (Gmaz et al, 2012).

Addiction pathology is neurally defined in part by hypofunction of the PFC, and reduced PFC output is thought to contribute to the loss of behavioral control to drug-paired stimuli that accompanies the development of compulsive drug-seeking behavior (Kalivas and Volkow, 2005). Although not yet studied in solvent-exposed animals, the intrinsic excitability of mPFC neurons from rodents who compulsively seek cocaine even in the face of a noxious stimulus is severely inhibited, and rodents who receive 'therapy' by optogenetic excitation of the mPFC during abstinence show reduced drug seeking (Chen et al, 2013). Altogether, the evidence points to the mPFC as a critical node in the addiction neurocircuitry that is altered by both acute and chronic drug use. In addition, by disinhibiting mesolimbic DA activity, a hypofunctional mPFC likely results in leftward shift in the ability of drugs to promote changes in synaptic plasticity, biasing the reward

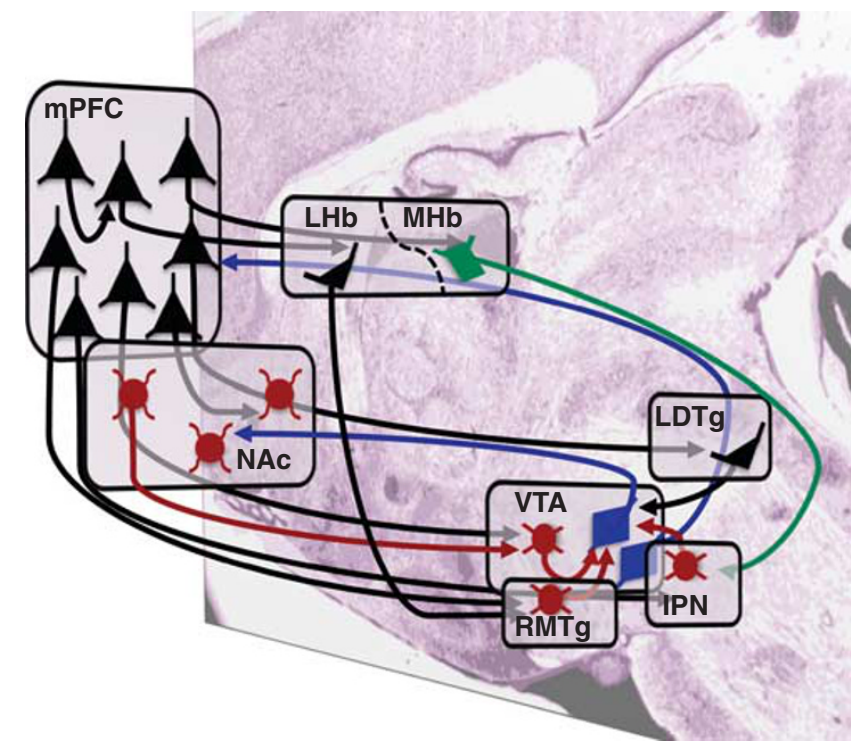

Figure 4 The medial prefrontal cortex inhibits the mesolimbic DA pathway through several different transsynaptic circuits. This wiring diagram is overlaying a sagittal section $\sim$ I mm from midline, stained with cresyl violet Nissl stain (Paxinos and Watson, 2005). Black-glutamate, redGABA, blue-dopamine, green-mix (acetylcholine, substance P). IPN, interpeduncular nucleus; LDTg, lateral dorsal tegmentum; LHb, lateral habenula; $\mathrm{mHB}$, medial habenula; $\mathrm{mPFC}$, medial prefrontal cortex; NAc, nucleus accumbens; RMTg, rostromedial tegmentum; VTA, ventral tegmental area.

pathways to normally sub-threshold concentrations of abused drugs.

In terms of abuse of volatile solvents and possibly other abused drugs, we propose that the prefrontal cortex may be one factor that critically gates the reinforcing effects of solvent exposure via its control over drug-induced adaptations in mesolimbic circuitry. A corollary to this hypothesis is that the state of PFC activity or output corresponds to an individual's likelihood of engaging in compulsive drug seeking when given free access to the abused compound. The PFC does not fully mature until early adulthood, and the progression of PFC development can be strongly altered by drugs of abuse, stress, social relationships, and maternal interactions (Kolb et al, 2012). Because volatile solvents are most widely abused by adolescents, a time-period that occurs well before the PFC is fully developed and solvents may have profound effects on the ability of the PFC to affect behavioral output.

Alterations in $\mathrm{mPFC}$ activity that arise during the progression from acute drug use to compulsive drug seeking are complex. With acute solvent use, pharmacological activation of the mPFC blocks toluene-induced adaptations of mesolimbic dopamine neuron activity (Beckley et al, 2013). Following chronic drug use, the mPFC, and specifically the corticostriatal pathway, is less dynamic and responds preferentially to drug-salient cues over neutral cues (Kalivas et al, 2005). Engaging the PFC early in adolescence or when there are signs of delayed cognitive development may be an effective way to slow or stop the potential progression from acute drug use to habitual chronic abuse. The PFC receives multi-sensory input, modulates signals based on the current state and historical representations, and then sends directed output to promote specific motor 
responses. This process is severely impaired in drug addicts (Kalivas and Volkow, 2005), and there is evidence that it is already impaired in those who may be vulnerable to drug addiction pathology. To wit, those dependent on psychostimulants and their non-drug-dependent siblings show impairments in response inhibition and executive function (Ersche et al, 2012). Similarly, non-alcohol-abusing individuals that have a family history of alcoholism show impulsive responding, with a concomitant elevated activation in the left anterior insula and inferior frontal gyrus compared with non-drug abusers with no family history of alcoholism (Devito et al, 2013). Overall, further research is necessary to determine how in vivo solvent exposure affects mPFC function. We would predict that adolescent solvent abuse leads to an altered mPFC state during adulthood with a concomitant increase in sensitivity to drug-induced excitatory synaptic alterations on mesolimbic DA neurons. We are not aware of any preclinical or clinical studies that examine the impact of adolescent solvent abuse on adult behavioral response or mesolimbic system activity due to drugs of abuse, but this is one of the critical research questions regarding solvent abuse, as it is clear that adolescents are the predominant abusers of volatile solvents.

\section{CONCLUSION}

Compared with other drugs of abuse, funding provided to support basic and clinical research on volatile solvents is less despite the worldwide abuse of these compounds for their intoxicating properties. Furthermore, adolescents are more likely to abuse volatile solvents than other age groups, and chronic abuse of solvents may profoundly alter development of the adolescent brain, particularly the PFC. Although their pharmacological heterogeneity and volatile nature make research on solvents somewhat more complex than that for more selective drugs of abuse like cocaine, the prevalence of solvent abuse worldwide, strong addiction liability, and impairment they confer on cognitive processing make it critical that solvents are given the research attention that they deserve.

Additionally, the PFC's ability to regulate the mesolimbic pathway is likely an important determinant of the magnitude of drug-induced plasticity. The PFC is involved in the entire spectrum of voluntary drug-taking, and basal neuronal activity changes as drug use progresses from acute intoxication to chronic drug seeking. Because solvents acutely inhibit PFC output and impair cognitive processing, exposure to solvent vapor may have a multiplicative impact on the mesolimbic dopamine system, by (1) directly enhancing DA neuron activity, and (2) by removing a major brake on mesolimbic DA pathway output. In sum, volatile solvents clearly are psychoactive chemicals with reinforcing properties, and their abuse liability is to due their ability to induce neuroadaptations in key regions of the addiction neurocircuitry.

\section{FUNDING AND DISCLOSURE}

This work was supported by NIH/NIDA grants DA010951 to JJW and DA030891 to JTB. The authors declare no conflict of interest.

\section{REFERENCES}

Aragona BJ, Cleaveland NA, Stuber GD, Day JJ, Carelli RM, Wightman RM (2008). Preferential enhancement of dopamine transmission within the nucleus accumbens shell by cocaine is attributable to a direct increase in phasic dopamine release events. J Neurosci 28: 8821-8831.

Argilli E, Sibley DR, Malenka RC, England PM, Bonci A (2008). Mechanism and time course of cocaine-induced long-term potentiation in the ventral tegmental area. JNeurosci 28: 9092-9100.

Aston-Jones G, Smith RJ, Moorman DE, Richardson KA (2009). Role of lateral hypothalamic orexin neurons in reward processing and addiction. Neuropharmacology 56(Suppl 1): 112-121.

Bale AS, Smothers CT, Woodward JJ (2002). Inhibition of neuronal nicotinic acetylcholine receptors by the abused solvent, toluene. Br J Pharmacol 137: 375-383.

Bale AS, Tu Y, Carpenter-Hyland EP, Chandler LJ, Woodward JJ (2005). Alterations in glutamatergic and gabaergic ion channel activity in hippocampal neurons following exposure to the abused inhalant toluene. Neuroscience 130: 197-206.

Balleine BW, Delgado MR, Hikosaka O (2007). The role of the dorsal striatum in reward and decision-making. J Neurosci 27: 8161-8165.

Balster RL (1998). Neural basis of inhalant abuse. Drug Alcohol Depend 51: 207-214.

Batis JC, Hannigan JH, Bowen SE (2010). Differential effects of inhaled toluene on locomotor activity in adolescent and adult rats. Pharmacol Biochem Behav 96: 438-448.

Beauvais F, Wayman JC, Jumper-Thurman P, Plested B, Helm H (2002). Inhalant abuse among American Indian, Mexican American, and non-Latino white adolescents. Am J Drug Alcohol Abuse 28: 171-187.

Beckley JT, Evins CE, Fedarovich H, Gilstrap MJ, Woodward JJ (2013). Medial prefrontal cortex inversely regulates tolueneinduced changes in markers of synaptic plasticity of mesolimbic dopamine neurons. J Neurosci 33: 804-813.

Beckley JT, Woodward JJ (2011). The abused inhalant toluene differentially modulates excitatory and inhibitory synaptic transmission in deep-layer neurons of the medial prefrontal cortex. Neuropsychopharmacology 36: 1531-1542.

Beckstead MJ, Phelan R, Mihic SJ (2001). Antagonism of inhalant and volatile anesthetic enhancement of glycine receptor function. J Biol Chem 276: 24959-24964.

Beckstead MJ, Weiner JL, Eger EI 2nd, Gong DH, Mihic SJ (2000). Glycine and gamma-aminobutyric acid(A) receptor function is enhanced by inhaled drugs of abuse. Mol Pharmacol 57: 1199-1205.

Benignus VA (1981). Health effects of toluene: a review. Neurotoxicology 2: 567-588.

Benignus VA, Muller KE, Barton CN, Bittikofer JA (1981). Toluene levels in blood and brain of rats during and after respiratory exposure. Toxicol Appl Pharmacol 61: 326-334.

Beyer CE, Stafford D, LeSage MG, Glowa JR, Steketee JD (2001). Repeated exposure to inhaled toluene induces behavioral and neurochemical cross-sensitization to cocaine in rats. Psychopharmacology 154: 198-204.

Bjorklund A, Dunnett SB (2007). Dopamine neuron systems in the brain: an update. Trends Neurosci 30: 194-202.

Blokhina EA, Dravolina OA, Bespalov AY, Balster RL, Zvartau EE (2004). Intravenous self-administration of abused solvents and anesthetics in mice. Eur J Pharmacol 485: 211-218.

Bowen SE (2006). Increases in amphetamine-like discriminative stimulus effects of the abused inhalant toluene in mice. Psychopharmacology 186: 517-524.

Bowen SE, Batis JC, Paez-Martinez N, Cruz SL (2006). The last decade of solvent research in animal models of abuse: 
mechanistic and behavioral studies. Neurotoxicol Teratol 28: 636-647.

Cairney S, Maruff P, Burns C, Currie B (2002). The neurobehavioural consequences of petrol (gasoline) sniffing. Neurosci Biobehav Rev 26: 81-89.

Campbell AD, McBride WJ (1995). Serotonin-3 receptor and ethanol-stimulated dopamine release in the nucleus accumbens. Pharmacol Biochem Behav 51: 835-842.

Carr DB, Sesack SR (2000). Projections from the rat prefrontal cortex to the ventral tegmental area: target specificity in the synaptic associations with mesoaccumbens and mesocortical neurons. J Neurosci 20: 3864-3873.

Chen BT, Yau H-J, Hatch C, Kusumoto-Yoshida I, Cho SL, Hopf FW et al (2013). Rescuing cocaine-induced prefrontal cortex hypoactivity prevents compulsive cocaine seeking. Nature 496: 359-362.

Christoph GR, Leonzio RJ, Wilcox KS (1986). Stimulation of the lateral habenula inhibits dopamine-containing neurons in the substantia nigra and ventral tegmental area of the rat. J Neurosci 6: 613-619.

Clinger OW, Johnson NA (1951). Purposeful inhalation of gasoline vapors. Psychiatr Q 25: 557-567.

Cruz SL, Balster RL, Woodward JJ (2000). Effects of volatile solvents on recombinant N-methyl-D-aspartate receptors expressed in Xenopus oocytes. Br J Pharmacol 131: 1303-1308.

Cruz SL, Mirshahi T, Thomas B, Balster RL, Woodward JJ (1998). Effects of the abused solvent toluene on recombinant N-methyl$\mathrm{D}$-aspartate and non-N-methyl-D-aspartate receptors expressed in Xenopus oocytes. J Pharmacol Exp Ther 286: 334-340.

Cruz SL, Orta-Salazar G, Gauthereau MY, Millian-Perez Peña L, Salinas-Stefanón EM (2003). Inhibition of cardiac sodium currents by toluene exposure. Br J Pharmacol 140: 653-660.

Curtis CE, D’Esposito M (2003). Persistent activity in the prefrontal cortex during working memory. Trends Cogn Sci 7: $415-423$.

Curtis CE, Lee D (2010). Beyond working memory: the role of persistent activity in decision making. Trends Cogn Sci 14: 216-222.

Dalley JW, Cardinal RN, Robbins TW (2004). Prefrontal executive and cognitive functions in rodents: neural and neurochemical substrates. Neurosci Biobehav Rev 28: 771-784.

Del Re AM, Dopico AM, Woodward JJ (2006). Effects of the abused inhalant toluene on ethanol-sensitive potassium channels expressed in oocytes. Brain Res 1087: 75-82.

Del Re AM, Woodward JJ (2005). Inhibition of gap junction currents by the abused solvent toluene. Drug Alcohol Depend 78: 221-224.

Devito EE, Meda SA, Jiantonio R, Potenza MN, Krystal JH, Pearlson GD (2013). Neural correlates of impulsivity in healthy males and females with family-histories of alcoholism. Neuropsychopharmacology 38: 1854-1863.

Di Chiara G, Imperato A (1988). Drugs abused by humans preferentially increase synaptic dopamine concentrations in the mesolimbic system of freely moving rats. Proc Natl Acad SciUSA 85: 5274-5278.

Dingwall KM, Cairney S (2011). Recovery from central nervous system changes following volatile substance misuse. Subst Use Misuse 46(Suppl 1): 73-83.

Dingwall KM, Maruff P, Fredrickson A, Cairney S (2011). Cognitive recovery during and after treatment for volatile solvent abuse. Drug Alcohol Depend 118: 180-185.

Driscoll DL, Dotterrer B, Collins D, Ogilvie K, Grube J, Johnson K (2012). Demographic and contextual factors associated with inhalant use among youth in rural Alaska. Intl J Circumpolar Health 1: 1-4.

Emmanouil DE, Quock RM (2007). Advances in understanding the actions of nitrous oxide. Anesthesia Prog 54: 9-18.

Ersche KD, Turton AJ, Chamberlain SR, Müller U, Bullmore ET, Robbins TW (2012). Cognitive dysfunction and anxious- impulsive personality traits are endophenotypes for drug dependence. Am J Psychiatry 169: 926-936.

Everitt BJ, Robbins TW (2005). Neural systems of reinforcement for drug addiction: from actions to habits to compulsion. Nat Neurosci 8: 1481-1489.

Ford CP, Mark GP, Williams JT (2006). Properties and opioid inhibition of mesolimbic dopamine neurons vary according to target location. J Neurosci 26: 2788-2797.

Fornazzari L, Wilkinson D a, Kapur BM, Carlen PL (1983). Cerebellar, cortical and functional impairment in toluene abusers. Acta Neurologica Scandinavica 67: 319-329.

Freedenthal S, Vaughn MG, Jenson JM, Howard MO (2007). Inhalant use and suicidality among incarcerated youth. Drug Alcohol Depend 90: 81-88.

Funada M, Sato M, Makino Y, Wada K (2002). Evaluation of rewarding effect of toluene by the conditioned place preference procedure in mice. Brain Res Protoc 10: 47-54.

Gabbott PL, Warner TA, Jays PR, Salway P, Busby SJ (2005). Prefrontal cortex in the rat: projections to subcortical autonomic, motor, and limbic centers. J Comp Neurol 492: $145-177$.

Gao M, Liu CL, Yang S, Jin GZ, Bunney BS, Shi WX (2007). Functional coupling between the prefrontal cortex and dopamine neurons in the ventral tegmental area. J Neurosci 27: 5414-5421.

Garcia HD (1996). Toluene. In: Spacecraft Maximum Allowable Concentrations for Selected Airborne Contaminants Vol 2 (The National Academies, National Research Council: Washington, DC.

Gauthereau MY, Salinas-Stefanón EM, Cruz SL (2005). A mutation in the local anaesthetic binding site abolishes toluene effects in sodium channels. Eur J Pharmacol 528: 17-26.

Garland EL, Howard MO, Vaughn MG, Perron BE (2011). Volatile substance misuse in the United States. Subst Use Misuse 46(Suppl 1): 8-20.

Gerasimov MR, Collier L, Ferrieri A, Alexoff D, Lee D, Gifford AN et al (2003). Toluene inhalation produces a conditioned place preference in rats. Eur J Pharmacol 477: 45-52.

Gerasimov MR, Schiffer WK, Marstellar D, Ferrieri R, Alexoff D, Dewey SL (2002). Toluene inhalation produces regionally specific changes in extracellular dopamine. Drug Alcohol Depend 65: 243-251.

Girod R, Barazangi N, McGehee D, Role LW (2000). Facilitation of glutamatergic neurotransmission by presynaptic nicotinic acetylcholine receptors. Neuropharmacology 39: 2715-2725.

Glaser HH, Massengale ON (1962). Glue-sniffing in children: deliberate inhalation of vaporized plastic cements. J Am Med Assoc 181: 90-93.

Gmaz JM, Yang L, Ahrari A, McKay BE (2012). Binge inhalation of toluene vapor produces dissociable motor and cognitive dysfunction in water maze tasks. Behav Pharmacol 23: 669-677.

Grady SR, Moretti M, Zoli M, Marks MJ, Zanardi A, Pucci L et al (2009). Rodent habenulo-interpeduncular pathway expresses a large variety of uncommon nAChR subtypes, but only the alpha3beta $4^{\star}$ and alpha3beta3beta $4^{\star}$ subtypes mediate acetylcholine release. J Neurosci 29: 2272-2282.

Groenewegen HJ, Berendse HW, Haber SN (1993). Organization of the output of the ventral striatopallidal system in the rat: ventral pallidal efferents. Neuroscience 57: 113-142.

Haber SN, Fudge JL, McFarland NR (2000). Striatonigrostriatal pathways in primates form an ascending spiral from the shell to the dorsolateral striatum. J Neurosci 20: 2369-2382.

Hathaway GJ, Proctor NH (2004). Proctor and Hughes' Chemical Hazards of the Workplace. 5th edn. John Wiley \& Sons, Inc.: Hoboken, NJ, pp 681-682.

Heikkinen AE, Moykkynen TP, Korpi ER (2009). Long-lasting modulation of glutamatergic transmission in VTA dopamine 
neurons after a single dose of benzodiazepine agonists. Neuropsychopharmacology 34: 290-298.

Hormes JT, Filley CM, Rosenberg NL (1986). Neurologic sequelae of chronic solvent vapor abuse. Neurology 36: 698-702.

Humphries MD, Prescott TJ (2010). The ventral basal ganglia, a selection mechanism at the crossroads of space, strategy, and reward. Prog Neurobiol 90: 385-417.

Hynes-Dowell M, Mateu-Gelabert P, Barros HMT, Delva J (2011). Volatile substance misuse among high school students in South America. Subst Use Misuse 46(Suppl 1): 27-34.

Ikemoto S (2007). Dopamine reward circuitry: two projection systems from the ventral midbrain to the nucleus accumbens-olfactory tubercle complex. Brain Res Rev 56: 27-78.

Jhou TC, Geisler S, Marinelli M, Degarmo BA, Zahm DS (2009). The mesopontine rostromedial tegmental nucleus: a structure targeted by the lateral habenula that projects to the ventral tegmental area of Tsai and substantia nigra compacta. J Comp Neurol 513: 566-596.

Ji H, Shepard PD (2007). Lateral habenula stimulation inhibits rat midbrain dopamine neurons through a GABA(A) receptormediated mechanism. J Neurosci 27: 6923-6930.

Johnston LD, O’Malley PM, Bachman JG, Schulenberg JE (2013). Monitoring the Future National Results on Adolescent Drug Use: Overview of Key Findings, 2012. Institute for Social Research, University of Michigan: Ann Arbor, MI.

Kalivas PW, Volkow N, Seamans J (2005). Unmanageable motivation in addiction: a pathology in prefrontal-accumbens glutamate transmission. Neuron 45: 647-650.

Kalivas PW, Volkow ND (2005). The neural basis of addiction: a pathology of motivation and choice. Am J Psych 162: 1403-1413.

Kamran S, Bakshi R (1998). MRI in chronic toluene abuse: low signal in the cerebral cortex on T2-weighted images. Neuroradiology 40: 519-521.

Kaufling J, Veinante P, Pawlowski SA, Freund-Mercier MJ, Barrot $M$ (2009). Afferents to the GABAergic tail of the ventral tegmental area in the rat. J Comp Neurol 513: 597-621.

Kawaja MD, Flumerfelt BA, Hrycyshyn AW (1989). Glutamate decarboxylase immunoreactivity in the rat interpeduncular nucleus: a light and electron microscope investigation. Neuroscience 30: 741-753.

Kikuchi A, Wada K (2003). Factors associated with volatile solvent use among junior high school students in Kanto, Japan. Addiction 98: 771-784.

Kim U, Lee T (2012). Topography of descending projections from anterior insular and medial prefrontal regions to the lateral habenula of the epithalamus in the rat. Eur J Neurosci 35: 1253-1269.

Koga Y, Higashi S, Kawahara H, Ohsumi T (2007). Toluene inhalation increases extracellular noradrenaline and dopamine in the medial prefrontal cortex and nucleus accumbens in freelymoving rats. J Kyushu Dental Soc 61: 39-54.

Kolb B, Mychasiuk R, Muhammad A, Li Y, Frost DO, Gibb R (2012). Experience and the developing prefrontal cortex. Proc Natl Acad Sci USA 109: 17186-17193.

Kurtzman TL, Otsuka KN, Wahl RA (2001). Inhalant abuse by adolescents. J Adolesc Health 28: 170-180.

Lacy BW, Ditzler TF (2007). Inhalant abuse in the military: an unrecognized threat. Mil Med 172: 388-392.

Lammel S, Hetzel A, Hackel O, Jones I, Liss B, Roeper J (2008). Unique properties of mesoprefrontal neurons within a dual mesocorticolimbic dopamine system. Neuron 57: 760-773.

Lammel S, Ion DI, Roeper J, Malenka RC (2011). Projectionspecific modulation of dopamine neuron synapses by aversive and rewarding stimuli. Neuron 70: 855-862.
Lammel S, Lim BK, Ran C, Huang KW, Betley MJ, Tye KM et al (2012). Input-specific control of reward and aversion in the ventral tegmental area. Nature 491: 212-217.

Lee DE, Gerasimov MR, Schiffer WK, Gifford AN (2006). Concentration-dependent conditioned place preference to inhaled toluene vapors in rats. Drug Alcohol Depend 85: 87-90.

Lo P-S, Wu C-Y, Sue H-Z, Chen H-H (2009). Acute neurobehavioral effects of toluene: involvement of dopamine and NMDA receptors. Toxicol 265: 34-40.

Lodge DJ (2011). The medial prefrontal and orbitofrontal cortices differentially regulate dopamine system function. Neuropsychopharmacology 36: 1227-1236.

Lopez-Quintero C, Neumark Y (2011). The epidemiology of volatile substance misuse among school children in Bogotá, Colombia. Subst Use Misuse 46(Suppl 1): 50-56.

Lopreato GF, Phelan R, Borghese CM, Beckstead MJ, Mihic SJ (2003). Inhaled drugs of abuse enhance serotonin-3 receptor function. Drug Alcohol Depend 70: 11-15.

Lubman DI, Yücel M, Lawrence a J (2008). Inhalant abuse among adolescents: neurobiological considerations. Br J Pharmacol 154: 316-326.

MacIver MB (2009). Abused inhalants enhance GABAmediated synaptic inhibition. Neuropsychopharmacology 34: 2296-2304.

Mameli M, Halbout B, Creton C, Engblom D, Parkitna JR, Spanagel R et al (2009). Cocaine-evoked synaptic plasticity: persistence in the VTA triggers adaptations in the NAc. Nat Neurosci 12: 1036-1041.

Mansvelder HD, McGehee DS (2000). Long-term potentiation of excitatory inputs to brain reward areas by nicotine. Neuron 27: 349-357.

Marsolek MR, White NC, Litovitz TL (2010). Inhalant abuse: monitoring trends by using poison control data, 1993-2008. Pediatrics 125: 906-913.

Martino SC, Klein DJ, McCaffrey DF, Erickson PL (2009). Recanting of lifetime inhalant use: how big a problem and what to make of it. Addiction 104: 1373-1381.

Maurice N, Deniau JM, Glowinski J, Thierry AM (1999). Relationships between the prefrontal cortex and the basal ganglia in the rat: physiology of the cortico-nigral circuits. J Neurosci 19: 4674-4681.

Mihic SJ, Harris RA (1996). Inhibition of rhol GABAergic currents by alcohol and volatile anesthetics. J Pharmacol Exp Ther 277: 411-416.

Mihic SJ, Ye Q, Wick MJ, Koltchine VV, Krasowski MD, Finn SE et al (1997). Sites of alcohol and volatile anaesthetic action on GABA(A) and glycine receptors. Nature 389: 385-389.

Miyata H, Kono J, Ushijima S, Yanagita T, Miyasato K, Fukui K (2004). Clinical features of nicotine dependence compared with those of alcohol, methamphetamine, and inhalant dependence. Ann N Y Acad Sci 1025: 481-488.

Myrick H, Anton RF, Li X, Henderson S, Randall PK, Voronin K (2008). Effect of naltrexone and ondansetron on alcohol cue-induced activation of the ventral striatum in alcoholdependent people. Arch Gen Psychiatry 65: 466-475.

Nishikawa T, Fage D, Scatton B (1986). Evidence for, and nature of, the tonic inhibitory influence of habenulointerpeduncular pathways upon cerebral dopaminergic transmission in the rat. Brain Res 373: 324-336.

Nonnemaker JM, Crankshaw EC, Shive DR, Hussin AH, Farrelly MC (2011). Inhalant use initiation among U.S. Adolescence: evidence from the National Survey of Parents and Youth using discreteTime Survival Analysis. Addict Behav 36: 878-881.

O’Doherty J, Dayan P, Schultz J, Deichmann R, Friston K, Dolan RJ (2004). Dissociable roles of ventral and dorsal striatum in instrumental conditioning. Science 304: 452-454.

O'Reilly RC (2006). Biologically based computational models of high-level cognition. Science 314: 91-94. 
Ogata J, Shiraishi M, Namba T, Smothers CT, Woodward JJ, Harris RA (2006). Effects of anesthetics on mutant N-methyl-D-aspartate receptors expressed in Xenopus oocytes. J Pharmacol Exp Ther 318: 434-443.

Omelchenko N, Sesack SR (2009). Ultrastructural analysis of local collaterals of rat ventral tegmental area neurons: GABA phenotype and synapses onto dopamine and GABA cells. Synapse 63: 895-906.

Paxinos G, Watson C (2005). The Rat Brain in Stereotaxic Coordinates. 5th edn. Elsevier Academic Press: Burlington, MA.

Rees DC, Coggeshall E, Balster RL (1985). Inhaled toluene produces pentobarbital-like discriminative stimulus effects in mice. Life Sci 37: 1319-1325.

Rees DC, Knisely JS, Balster RL, Jordan S, Breen TJ (1987a). Pentobarbital-like discriminative stimulus properties of halothane, 1,1,1-trichloroethane, isoamyl nitrite, flurothyl and oxazepam in mice. J Pharmacol Exp Ther 241: 507-515.

Rees DC, Knisely JS, Breen TJ, Balster RL (1987b). Toluene, halothane, 1,1,1-trichloroethane and oxazepam produce ethanollike discriminative stimulus effects in mice. J Pharmacol Exp Ther 243: 931-937.

Ridenour TA, Bray BC, Cottler LB (2007). Reliability of use, abuse, and dependence of four types of inhalants in adolescents and young adults. Drug Alcohol Depend 91: 40-49.

Riegel AC, Ali SF, French ED (2003). Toluene-induced locomotor activity is blocked by 6-hydroxydopamine lesions of the nucleus accumbens and the mGluR2/3 agonist LY379268. Neuropsychopharmacology 28: 1440-1447.

Riegel AC, French ED (1999). Acute toluene induces biphasic changes in rat spontaneous locomotor activity which are blocked by remoxipride. Pharmacol, Biochem Behav 62: 399-402.

Riegel AC, Zapata A, Shippenberg TS, French ED (2007). The abused inhalant toluene increases dopamine release in the nucleus accumbens by directly stimulating ventral tegmental area neurons. Neuropsychopharmacology 32: 1558-1569.

Rosenberg NL, Kleinschmidt-DeMasters BK, Davis KA, Dreisbach JN, Hormes JT, Filley CM (1988). Toluene abuse causes diffuse central nervous system white matter changes. Ann Neurol 23: 611-614.

Ryu YH, Lee JD, Yoon PH, Jeon P, Kim DI, Shin DW (1998). Cerebral perfusion impairment in a patient with toluene abuse. J Nucl Med 39: 632-633.

Saal D, Dong Y, Bonci A, Malenka RC (2003). Drugs of abuse and stress trigger a common synaptic adaptation in dopamine neurons. Neuron 37: 577-582.

Sakai JT, Hall SK, Mikulich-Gilbertson SK, Crowley TJ (2004). Inhalant use, abuse, and dependence among adolescent patients: commonly comorbid problems. J Am Acad Child Adolesc Psych 43: $1080-1088$.

Shafer TJ, Bushnell PJ, Benignus VA, Woodward JJ (2005). Perturbation of voltage-sensitive $\mathrm{Ca} 2+$ channel function by volatile organic solvents. J Pharmacol Exp Ther 315: 1109-1118.

Shelton KL (2009). Discriminative stimulus effects of inhaled 1,1,1trichloroethane in mice: comparison to other hydrocarbon vapors and volatile anesthetics. Psychopharmacology 203: $431-440$.

Shelton KL (2010). Pharmacological characterization of the discriminative stimulus of inhaled 1,1,1-trichloroethane. $J$ Pharmacol Exp Ther 333: 612-620.

Shelton KL, Nicholson KL (2012). GABAA-positive modulator selective discriminative stimulus effects of 1,1,1-trichloroethane vapor. Drug Alcohol Depend 121: 103-109.

Shelton KL, Slavova-Hernandez G (2009). Characterization of an inhaled toluene drug discrimination in mice: effect of exposure conditions and route of administration. Pharmacol, Biochem Behav 92: 614-620.

Stamatakis AM, Stuber GD (2012). Activation of lateral habenula inputs to the ventral midbrain promotes behavioral avoidance. Nat Neurosci 15: 1105-1107.
Sung KW, Engel SR, Allan AM, Lovinger DM (2000). 5HT(3) receptor function and potentiation by alcohols in frontal cortex neurons from transgenic mice overexpressing the receptor. Neuropharmacology 39: 2346-2351.

Takagi M, Lubman DI, Cotton S, Fornito A, Baliz Y, Tucker A, Yücel M (2011). Executive control among adolescent inhalant and cannabis users. Drug Alcohol Rev 30: 629-637.

Takagishi M, Chiba T (1991). Efferent projections of the infralimbic (area 25) region of the medial prefrontal cortex in the rat: an anterograde tracer PHA-L study. Brain Res 566: 26-39.

Tan KR, Yvon C, Turiault M, Mirzabekov JJ, Doehner J, Labouebe G et al (2012). GABA neurons of the VTA drive conditioned place aversion. Neuron 73: 1173-1183.

Tillar R, Shafer TJ, Woodward JJ (2002). Toluene inhibits voltagesensitive calcium channels expressed in pheochromocytoma cells. Neurochem Int 41: 391-397.

Tong ZY, Overton PG, Clark D (1996). Stimulation of the prefrontal cortex in the rat induces patterns of activity in midbrain dopaminergic neurons which resemble natural burst events. Synapse 22: 195-208.

Trantham-Davidson H, Lavin A (2004). Acute cocaine administration depresses cortical activity. Neuropsychopharmacology 29: 2046-2051.

Tsai HC, Zhang F, Adamantis A, Stuber GD, Bonci A, de Lecea L et al (2009). Phasic Firing in dopaminergic neurons is sufficient for behavioral conditioning. Science 324: 1080-1084.

Ungless MA, Whistler JL, Malenka RC, Bonci A (2001). Single cocaine exposure in vivo induces long-term potentiation in dopamine neurons. Nature 411: 583-587.

Usuda I, Tanaka K, Chiba T (1998). Efferent projections of the nucleus accumbens in the rat with special reference to subdivision of the nucleus: biotinylated dextran amine study. Brain Res 797: 73-93.

Van Zessen R, Phillips JL, Budygin EA, Stuber GD (2012). Activation of VTA GABA neurons disrupts reward consumption. Neuron 73: 1184-1194.

Važan P, Khan MR, Poduška O, Stastná L, Miovský M (2011). Chronic toluene misuse among Roma youth in Eastern Slovakia. Subst Use Misuse 46(Suppl 1): 57-61.

Villatoro JA, Cruz SL, Ortiz A, Medina-Mora ME (2011). Volatile substance misuse in Mexico: correlates and trends. Subst Use Misuse 46(Suppl 1): 40-45.

Watabe-Uchida M, Zhu L, Ogawa SK, Vamanrao A, Uchida N (2012). Whole-brain mapping of direct inputs to midbrain dopamine neurons. Neuron 74: 858-873.

Weir E (2001). Inhalant use and addiction in Canada. CMAJ 164: 397.

Weiss B, Wood RW, Macys DA (1979). Behavioral toxicology of carbon disulfide and toluene. Environ Health Perspect 30: $39-45$.

Williams JM, Stafford D, Steketee JD (2005). Effects of repeated inhalation of toluene on ionotropic GABA $A$ and glutamate receptor subunit levels in rat brain. Neurochem Int 46: $1-10$.

Woodward JJ, Nowak M, Davies DL (2004). Effects of the abused solvent toluene on recombinant $\mathrm{P} 2 \mathrm{X}$ receptors expressed in HEK293 cells. Mol Brain Res 125: 86-95.

World Health Organization (2000). Toluene. In: Air Quality Standards for Europe. WHO Regional Office for Europe: Copenhagen, Denmark.

Wu L-T, Howard MO (2007). Psychiatric disorders in inhalant users: results from The National Epidemiologic Survey on Alcohol and Related Conditions. Drug Alcohol Depend 88: 146-155.

Wu L-T, Woody GE, Wang C, Pan J-J, Blazer DG (2011). Racial/ ethnic variations in substance-related disorders among adolescents in the United States. JAMA Psych 68: 1176-1185. 
Xu T-X, Sotnikova TD, Liang C, Zhang J, Jung JU, Spealman RD et al (2009). Hyperdopaminergic tone erodes prefrontal longterm potential via a D2 receptor-operated protein phosphatase gate. J Neurosci 29: 14086-14099.

Yücel M, Takagi M, Walterfang M, Lubman DI (2008). Toluene misuse and long-term harms: a systematic review of the neuropsychological and neuroimaging literature. Neurosci Biobehav Rev 32: 910-926.
Yücel M, Zalesky A, Takagi MJ, Bora E, Fornito A, Ditchfield M et al (2010). White-matter abnormalities in adolescents with long-term inhalant and cannabis use: a diffusion magnetic resonance imaging study. J Psych Neurosci 35: 409-412.

Zubaran C, Foresti K, Thorell MR, Franceschini P, Homero W (2010). Depressive symptoms in crack and inhalant users in Southern Brazil. J Ethn Subst Abuse 9: 221-236. 